\title{
Pemodelan Hidrogeologi Cekungan Airtanah Samarinda-Bontang Segmen Penajam Dalam Upaya Konservasi Airtanah Berbasis Cekungan, Kabupaten Penajam Paser Utara, Provinsi Kalimantan Timur
}

\author{
Arizatur Reza Wicaksono ${ }^{1 *}$, Thomas Triadi Putranto ${ }^{1}$, Reddy Setyawan ${ }^{1}$ \\ Departemen Teknik Geologi Fakultas Teknik Universitas Diponegoro
}

\begin{abstract}
Abstrak
Peraturan Menteri ESDM No. 7 Tahun 2017 tentang Cekungan Airtanah pasal 2 ayat 3 menyebutkan bahwa sistem pengelolaan airtanah didasarkan pada Cekungan Airtanah, namun di Indonesia masih banyak daerah-daerah yang masih menggunakan sistem pengelolaan berbasis sumur produksi yang dibatasi pada wilayah administrasi. Tujuan dari penelitian ini adalah untuk membuat model numerik pada Cekungan Airtanah (CAT) Samarinda-Bontang segmen Penajam berdasarkan model konsep yang dibuat berdasarkan data-data di lapangan. Model nantinya akan digunakan sebagai acuan dalam menentukan rekomendasi terkait konservasi airtanah dari hasil simulasi model. Model numerik dibuat dengan memasukkan parameter-parameter hidrogeologi. Diskritisasi geometri dan iterasi berdasarkan metode beda hingga (finite differences method). Simulasi model yang dilakukan berdasarkan prediksi debit pemompaan hingga 20 tahun kedepan. Hasil kalibrasi model didapatkan nilai root mean squared error (RMSE) sebesar $0,75 \mathrm{~m}$, mean error (ME) sebesar $0,1 \mathrm{~m}$, dan mean absolute error (MAE) sebesar $0,63 \mathrm{~m}$, dengan nilai koefisien korelasi sebesar 0,944. Zona konservasi airtanah dibuat dengan mengkombinasikan persentase penurunan airtanah berdasarkan simulasi model skenario terburuk, daerah imbuhan-lepasan, dan nilai daya hantar listrik. Didapatkan 4 (empat) prediksi zona konservasi airtanah, yaitu: zona perlindungan airtanah seluas 107,69 $\mathrm{km}^{2}(26,39 \%)$ di sebelah timur CAT Samarinda-Bontang, zona aman seluas 229,35 km² (56,21\%) di sebelah timur CAT Samarinda-Bontang, zona rawan seluas $60,35 \mathrm{~km}^{2}(14,79 \%)$ di sebelah barat CAT Samarinda-Bontang, dan zona kritis seluas $10,64 \mathrm{~km}^{2}$ di sebelah barat CAT Samarinda-Bontang $(2,61 \%)$.
\end{abstract}

Kata kunci: airtanah, cekungan airtanah Samarinda-Bontang, pemodelan hidrogeologi, zona konservasi airtanah, MODFLOW.

\begin{abstract}
Based on Minister of Energy and Mineral Resources regulation No. 7 of 2017 concerned with Groundwater Basin article 2 paragraph 3 stated that groundwater management system was based on groundwater basin, but in Indonesia there were still many districts that still used production-based management system which was limited to administrative area. The purpose of this research was to make the hydrogeological model in Samarinda-Bontang Groundwater Basin segment Penajam based on conceptual model that made from field data. Model will be used as a reference in determining the recommendations related to groundwater conservation from the model simulation results. Numerical model was made by inputting hydrogeological parameters. Geometry discretization and iteration based on finite difference method. The model simulation based on abstraction of water discharge was done in 20 years ahead. Calibration model result obtained of RMSE value 0,75 m, ME value 0,1 $\mathrm{m}$ and MAE value 0,63 m, with correlation coefficient value 0,944. Groundwater conservation zones are created by combining percentage of groundwater decline based on the worst-case scenario model simulation, recharge-discharge areas, and electrical conductivity values in the study area. Result of 4 (four) predicted groundwater conservation zones are: groundwater protection zone covered $26,39 \%(107,69$ $\left.\mathrm{km}^{2}\right)$ in the eastern of groundwater basin, safe zone covered $229,35 \mathrm{~km}^{2}(56,21 \%)$ in the eastern of groundwater basin, vulnerable zones covered $60,35 \mathrm{~km}^{2}(14,79 \%)$ in the western of groundwater basin, and critical zones covered $10,64 \mathrm{~km}^{2}(2,61 \%)$ in the eastern of groundwater basin.
\end{abstract}

Keywords: Groundwater, Samarinda-Bontang Groundwater Basin, Hydrogeological Modelling, Conservation Zone, MODFLOW

*) Korespondensi: arizatur.reza.w@gmail.com 


\section{PENDAHULUAN}

Kabupaten Penajam Paser Utara sebagai kabupaten yang berkembang dengan jumlah penduduk sebesar 154.235 ribu jiwa (Badan Pusat Statistik Kabupaten Penajam Paser Utara, 2017) merupakan bagian dari CAT Samarinda-Bontang yaitu CAT lintas Kabupaten Kota yang membentang mulai dari Kabupaten Penajam Paser Utara hingga Kabupaten Kutai Timur. Bertambahnya populasi penduduk di Kabupaten Penajam Paser Utara berdampak pada kebutuhan air bersih yang semakin menigkat.

Berdasarkan Peraturan Menteri ESDM No. 2 Tahun 2017 tentang Cekungan Airtanah di Indonesia pasal 2 ayat 3, menjelaskan bahwa "Pengelolaan airtanah didasarkan pada cekungan airtanah". Diharapkan badan dan instansi pemerintah di bidang pengelolaan dan pengendalian sumber daya air menggunakan sistem pengelolaan airtanah berbasis cekungan airtanah.

Pengelolaan airtanah dalam arti luas adalah segala upaya yang mencakup inventarisasi, pengaturan pemanfaatan, perijinan, pengendalian serta pengawasan dalam rangka konservasi airtanah (Hendrayana, 2011). Konservasi airtanah merupakan upaya melindungi dan memelihara keberadaan, kondisi, dan lingkungan airtanah guna mempertahankan kelestarian atau ketersedian dalam kuantitas dan kualitas baik waktu sekarang maupun pada generasi yang akan datang (Danaryanto dkk., 2007). Dalam pengelolaan airtanah berbasis konservasi ketersediaan informasi hidrologi, hidrogeologi, geologi baik secara permukaan dan bawah permukaan sangat diperlukan dalam analisis dan evaluasi kondisi CAT. Untuk itu, model hidrogeologi merupakan salah satu metode yang dapat digunakan untuk meramalkan dan memprediksi kuantitas dan kualitas airtanah (Chow dkk., 1998).

Visual Modflow adalah perangkat lunak khusus yang dibuat untuk mengamati kondisi airtanah. Visual Modflow dapat menampilkan kondisi airtanah dalam dua dimensi dan tiga dimensi dengan menggunakan metode beda hingga (finite difference method) untuk melakukan pemodelan yaitu dengan cara membuat block centered grid sehingga yang diketahui adalah nilai pada tengah-tengah blok (Cornelia, 2004). Menurut McDonald dan Harbaugh (1988), Persamaan 1 merupakan persamaan yang mengatur pemodelan tiga dimensi pada perangkat lunak Visual Modflow.

$$
\begin{gathered}
\frac{\delta}{\delta x}\left(K_{x} \frac{\delta h}{\delta x}\right)+\frac{\delta}{\delta y}\left(K_{y} \frac{\delta h}{\delta y}\right)+\frac{\delta}{\delta z}\left(K_{z} \frac{\delta h}{\delta z}\right) \\
=S_{s} \frac{\delta h}{\delta t}-q s
\end{gathered}
$$

Keterangan:

$$
\begin{aligned}
& K=\text { Hydraulic conductivity } \\
& \text { Ss } \quad=\text { Specific storage } \\
& h \quad=\text { Hydraulic heads } \\
& \text { Qs = volumetric flux of ground water } \\
& \text { sources and sinks per unit volume }
\end{aligned}
$$

\section{Kondisi Geologi Regional}

Pengamatan geologi permukaan umumnya terdapat batuan hasil sedimentasi cekungan Kutai berumur Miosen tengah-Holosen, yaitu pada Formasi Balikpapan, Formasi Kampung Baru, dan endapan alluvium (Hidayat dan Umar, 1994). Adapun susunan stratigrafi di daerah penelitian terdiri atas (Gambar 3):

a. Endapan Alluvium, (Qa) yang tersusun oleh kerakal, kerikil, lempung dan lumpur sebagai endapan sungai, rawa, pantai dan delta.

b. Formasi Kampungbaru, (Tpkb) yang tersusun atas batu pasir kuarsa dengan sisipan lempung, lanau dan serpih.

c. Formasi Balikpapan, (Tmbp) yang terdiri atas perselingan batu pasir kuarsa, batu lempung lanauan dan serpih dengan sisipan napal, batugamping dan batubara.

d. Formasi Bebulu, (Tmbl) yang terdiri atas batugamping dengan sisipan batulempung dan sedikit napal.

Struktur geologi yang berkembang daerah penelitian berupa antiklin, yang dipengaruhi oleh fisiografi dari Antiklinorium Samarinda dengan orientasi dominan berarah timur laut-barat daya, serta terdapat beberapa sesar-sesar kecil (Hidayat dan Umar, 1994). Secara regional sistem akuifer merupakan sistem akuifer dengan aliran airtanah melalui antar butir dan aliran airtanah melalui celah dan ruang antar butir (Margono, 1995).

Dalam melakukan pemodelan CAT untuk penentuan prediksi zona konservasi airtanah digunakan kombinasi perangkat lunak Visual Modflow dan ArcGis berdasarkan data-data yang tersedia dilapangan dan referensi seperti data 
geologi, hidrogeologi, geofisika, dan klimatologi. Tujuan dari pemodelan CAT ini adalah sebagai acuan dalam menentukan rekomendasi terkait konservasi airtanah dari hasil simulasi model.

\section{METODOLOGI}

Pada penelitian ini menggunakan 2 (dua) metode yang gunakan yakni metode deskriptif dan metode analisis. Metode deskriptif dilakukan dengan mencari referensi yang berhubungan dengan topik penelitian (studi pustaka), mencari data geologi dan hidrogeologi langsung di lapangan (survei lapangan), dan analisis laboratorium dari hasil sampel airtanah yang didapatkan dari survei lapangan.

Metode analisis yang digunakan pada penelitian ini berupa analisis litologi di bawah permukaan, analisis hidrostratigrafi, analisis interpolasi, analisis sifat fisik dan kimia airtanah, dan analisis pemodelan dengan menggunakan perangkat lunak visual Modflow.

Adapun data sampel yang digunakan antara lain berupa:

a. Titik minatan hidrogeologi sebanyak 62 sampel (lokasi ditunjukkan pada Gambar 1), yang digunakan untuk analisis sifat fisik dan kimia aritanah (pH, DHL, dan TDS), untuk mengetahui ketinggian muka airtanah dan arah aliran airtanah. b. Titik pengukuran geolistrik dengan konfigurasi Schlumberger sebanyak 50 (lima puluh) titik pengukuran, yang digunakan untuk mengetahui resistivitas dan jenis batuan bawah permukaan (Gambar 2).

c. Titik pengukuran (stasiun) curah hujan sebanyak 4 (empat) lokasi, yang digunakan untuk interpolasi data hidrologi di daerah penelitian seperti temperatur $\left({ }^{\circ} \mathrm{C}\right)$, curah hujan (mm/tahun), evapotranspirasi (mm/tahun), air limpasan ( $\mathrm{mm} / \mathrm{tahun})$, dan imbuhan airtanah (mm/tahun).

Dari data sampel tersebut, kemudian dibuatlah model numerik dengan menggunakan perangkat lunak visual Modflow. Model tersebut nantinya akan dibuat skenario penurunan muka airtanah berdasarkan kondisi tertentu. Skenario ini digunakan sebagai acuan dalam penentuan prediksi zona konservasi airtanah. Sebanyak 4 skenario dibuat, yaitu:

a. Skenario I

Skenario I dibuat berdasarkan nilai debit yang diambil dari perhitungan debit prediksi yang berdasarkan pertumbuhan jumlah penduduk selama dua puluh tahun kedepan. Nilai debit prediksi yang dimasukkan kedalam model sebesar $239 \mathrm{~m}^{3} /$ hari pada tahun $2021 ; 261 \mathrm{~m}^{3} /$ hari pada tahun 2026; $283 \mathrm{~m}^{3} /$ hari pada tahun 2031 ; dan $305 \mathrm{~m}^{3} /$ hari pada tahun 2036 .

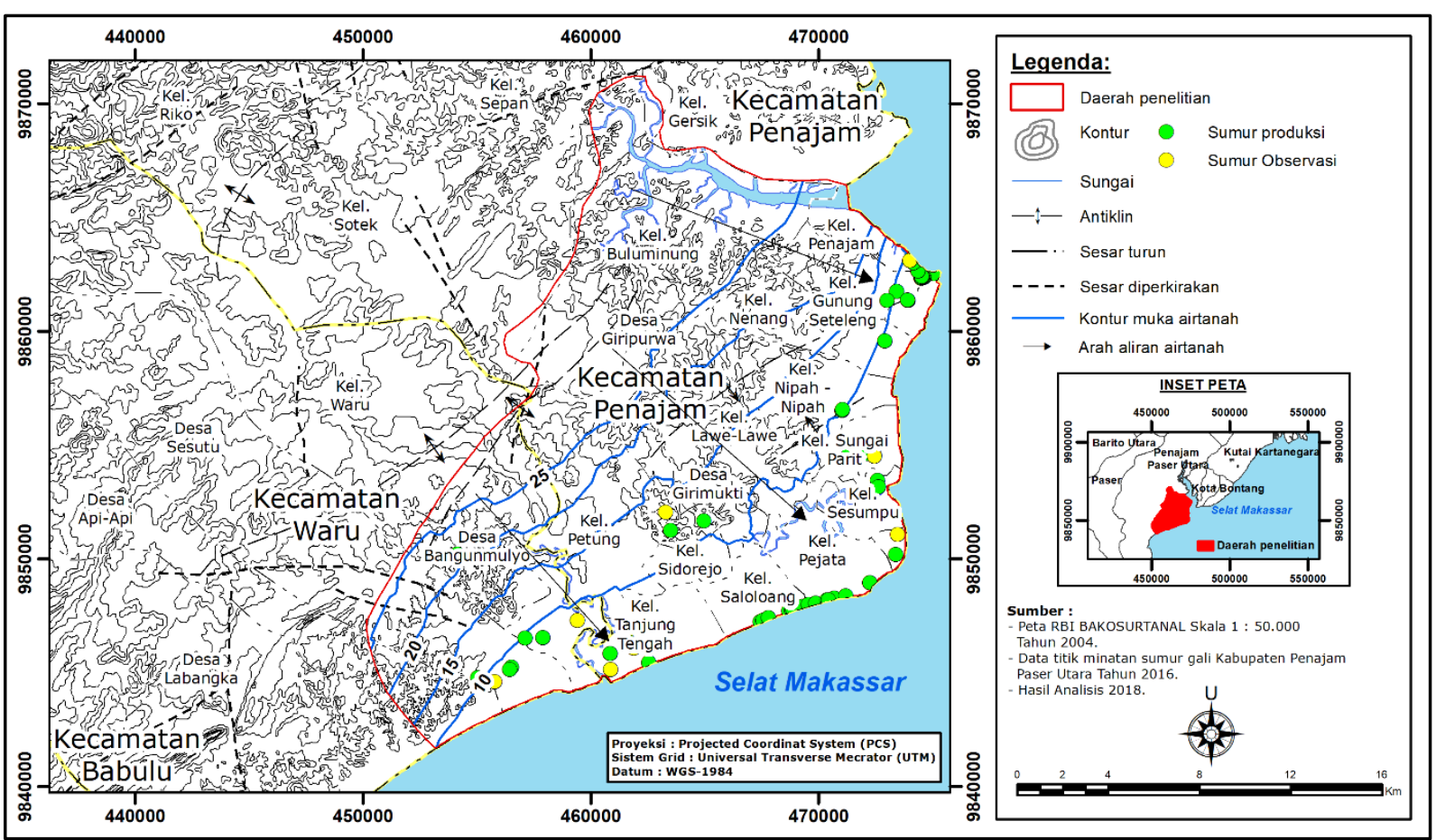

Gambar 1. Titik minatan hidrogeologi di daerah penelitian 


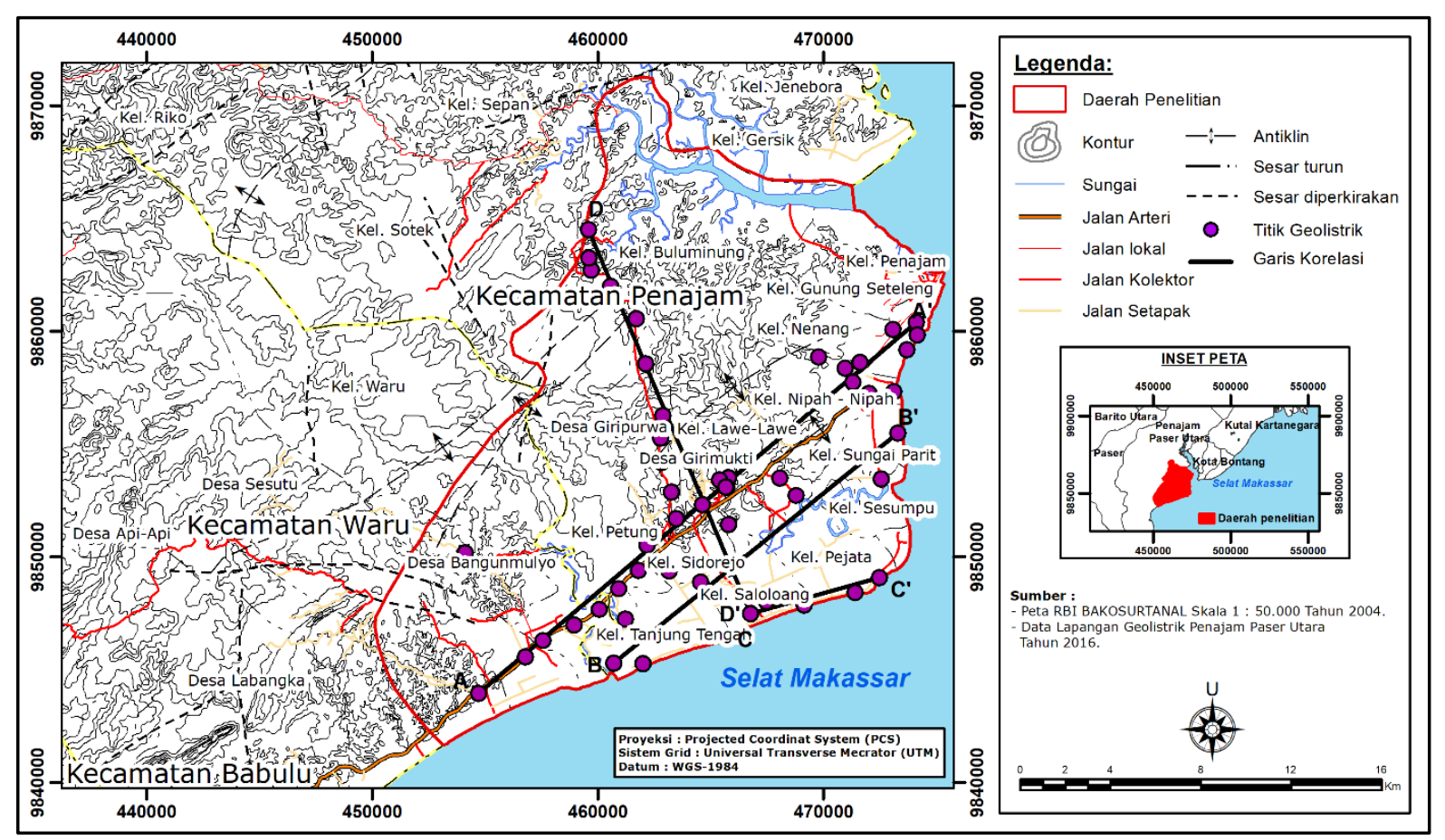

Gambar 2. Titik pengukuran geolistrik di daerah penelitian

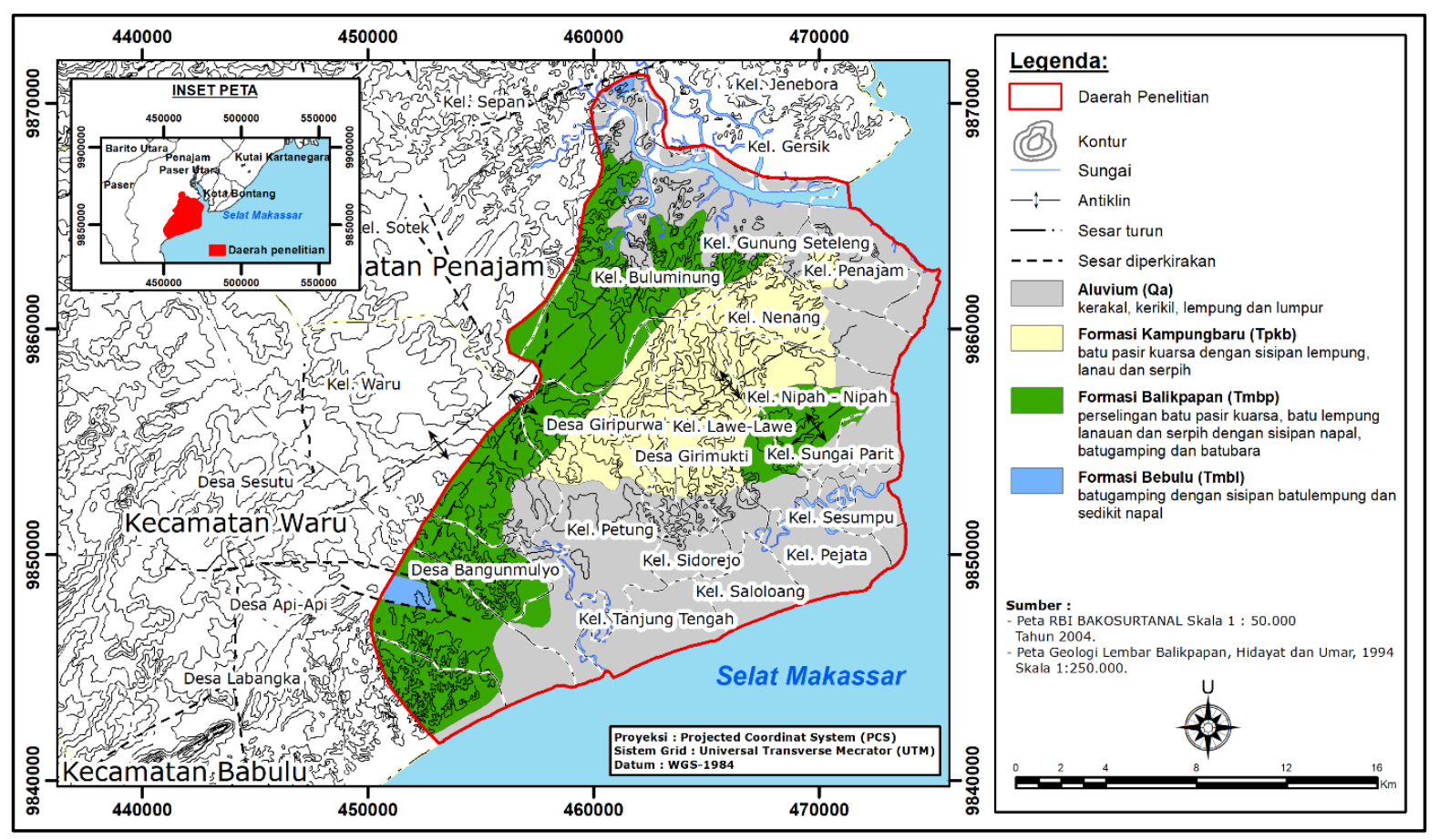

Gambar 3. Peta geologi regional di daerah penelitian (Hidayat dan Umar, 1994) 


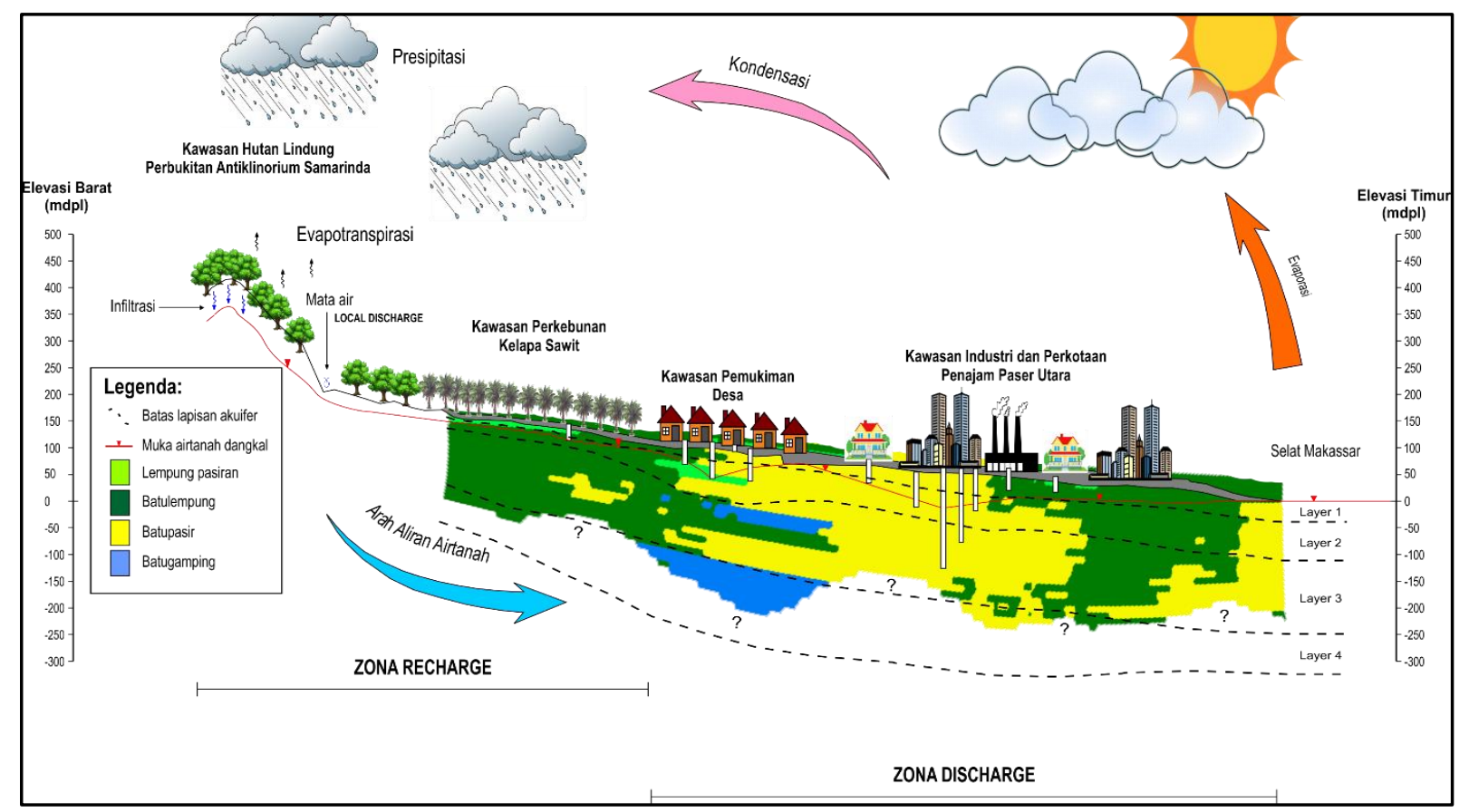

Gambar 4. Model konsep berbentuk penampang di daerah penelitian

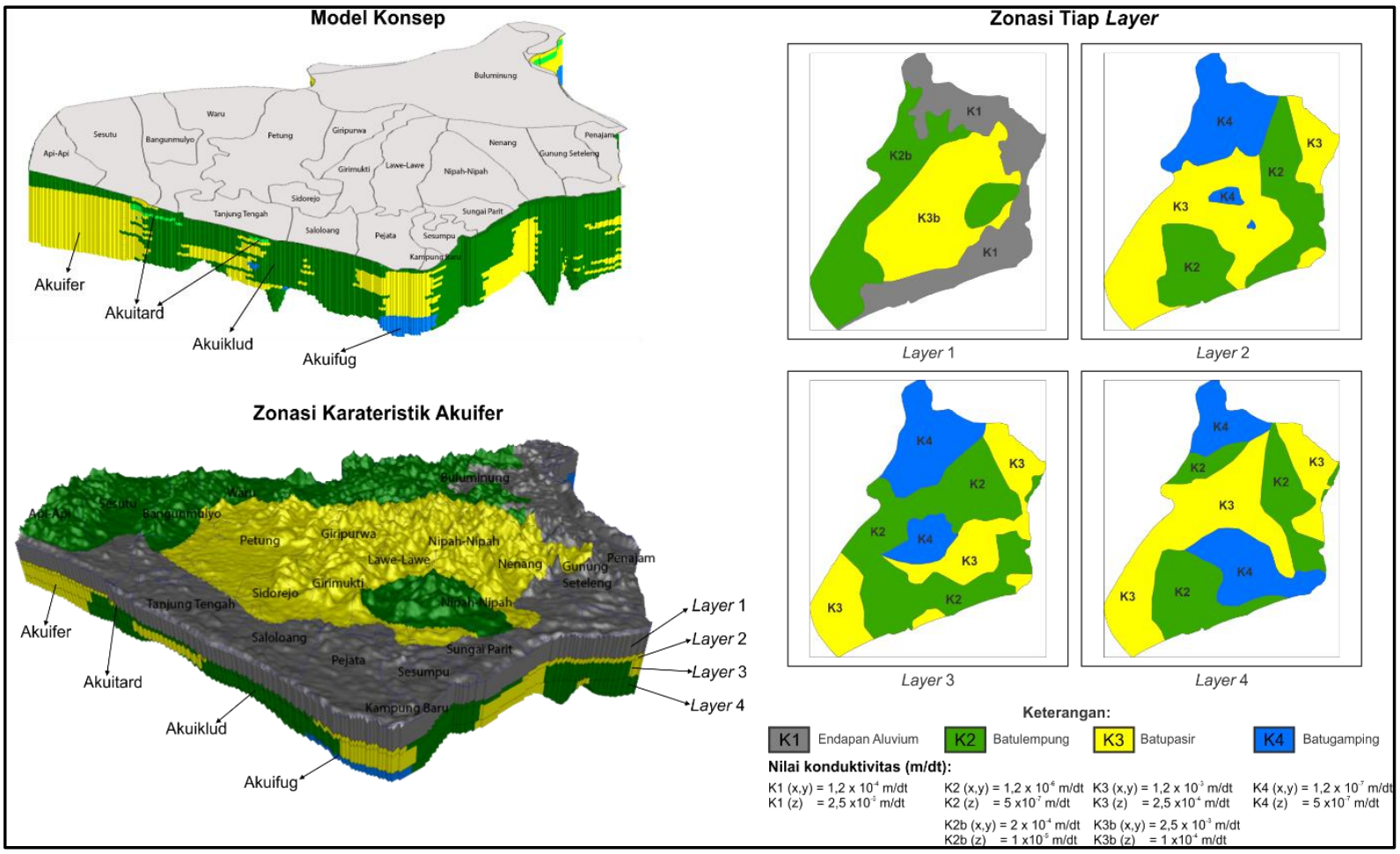

Gambar 5. Diskritisasi model dengan parameter masukan

b. Skenario II

Skenario II dilakukan berdasarkan nilai debit yang diambil dari perhitungan debit prediksi yang berdasarkan pertumbuhan jumlah penduduk dan sektor industri selama dua puluh tahun kedepan. Nilai debit prediksi yang dimasukkan kedalam model sebesar
$1252 \mathrm{~m}^{3}$ /hari pada tahun $2021 ; 1274 \mathrm{~m}^{3} /$ hari pada tahun 2026; $1296 \mathrm{~m}^{3} /$ hari pada tahun 2031; dan $1317 \mathrm{~m}^{3} /$ hari pada tahun 2036 .

c. Skenario III

Skenario III dibuat berdasarkan nilai debit yang diambil dari perhitungan debit prediksi yang diambil berdasarkan pertumbuhan 
jumlah penduduk dan sektor industri selama dua puluh tahun kedepan dengan faktorisasi 2. Nilai debit prediksi yang dimasukkan kedalam model sebesar $2.503 \mathrm{~m}^{3} /$ hari pada tahun 2021; $2.547 \mathrm{~m}^{3} /$ hari pada tahun $2026 ; 2.591 \mathrm{~m}^{3} /$ hari pada tahun 2031; dan $2.635 \mathrm{~m}^{3} /$ hari pada tahun 2036.

\section{HASIL}

\section{Model Konsep}

Berdasarkan hasil evaluasi dan analisis data lapangan, kondisi permukaan dan titik minatan, model konsep (Gambar 4) dapat dijelaskan sebagai berikut:

a. Daerah model dibatasi oleh batas hidrologi dibagian utara berupa batas tanpa aliran (noflow boundary); dibagian timur laut, timur, tenggara dibatasi oleh batas permukaan tetap (constant head boundary); dibagian barat daya dibatasi oleh batas tanpa aliran (noflow boundary); dibagian barat dan barat laut dibatasi oleh batas permukaan bebas (free surface boundary).

b. Daerah model terdiri dari empat unit layer, yaitu: Layer 1 dengan ketebalan 10-50 m merupakan lapisan akuifer bebas bagian dari endapan alluvium dan Formasi Kampungbaru (Tpkb); Layer 2 dengan ketebalan 10-40 m merupakan lapisan akuiklud, akuifer dan akuitard bagian dari Formasi Balikpapan bagian atas (Tmbp). Layer 3 dengan ketebalan 50-100 m terdiri lapisan akuiklud dan akuifer, merupakan bagian dari Formasi Balikpapan (Tmbp). Layer 4 dengan tebal 30-50 m merupakan lapisan akuitard, merupakan bagian dari Formasi Balikpapan (Tmbp).

c. Setiap layer dilakukan pembagian zonasi karateristik akuifer meliputi nilai konduktivitas hidraulika dan storativitas berdasarkan jenis akuifer dan litologi berdasarkan data lapangan dan data resistivitas batuan (Gambar 5).

Sistem aliran airtanah pada daerah penelitian berdasarkan hasil interpolasi didapatkan bahwa arah aliran airtanah mengalir relatif dari arah barat menuju timur, dengan nilai ketinggian muka airtanah (MAT) berkisar 0-25 m.

\section{Hasil Pemodelan Kondisi Awal}

Proses komputasi pada pemodelan kondisi awal dijalankan pada kondisi tunak (steady state). Hasil keluaran model (Gambar 6), merupakan

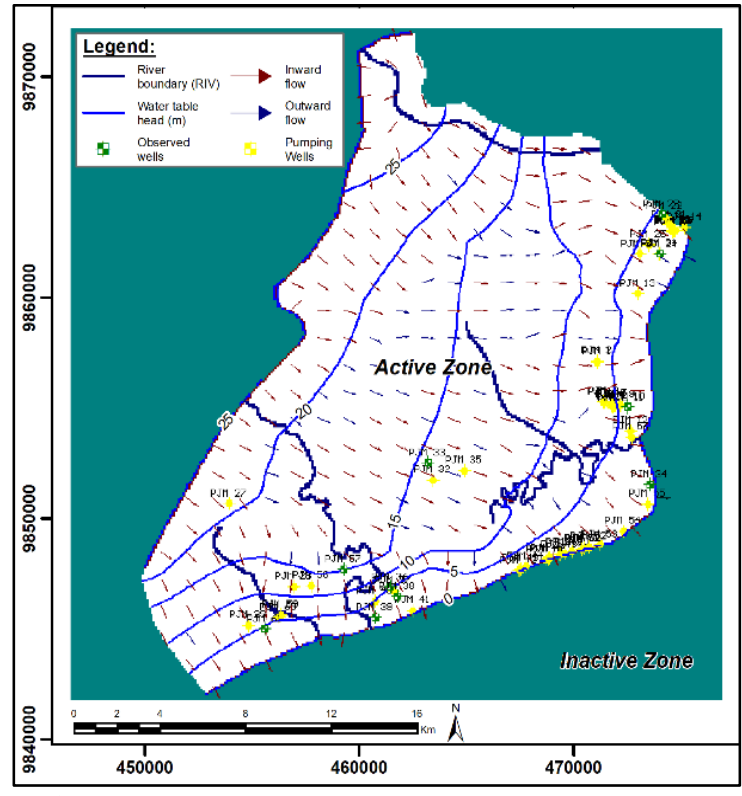

Gambar 6. Hasil pemodelan pada kondisi awal

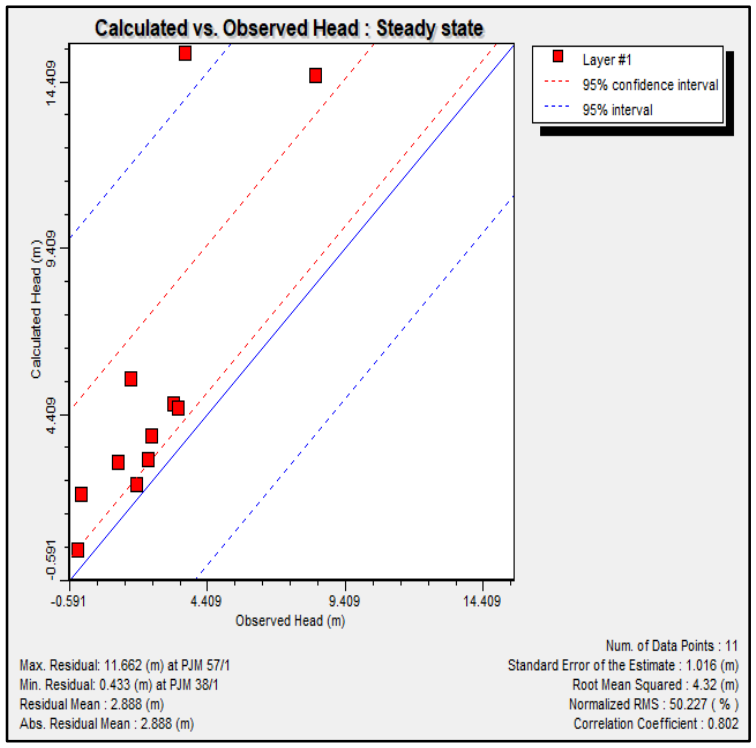

Gambar 7. Nilai kalibrasi model kondisi awal

hasil keluaran model pada layer 1 . Terlihat pada model kondisi awal tidak ditemukannya sel kering (dry cells), arah aliran muka airtanah sesuai dengan hasil interpolasi muka airtanah pada model konsep, yaitu relatif berarah barattimur.Kalibrasi model kondisi awal (Gambar 7) berupa nilai kesalahan akar kuadrat rata-rata sebesar 4,32 m, kesalahan rata-rata sebesar $1 \mathrm{~m}$, kesalahan mutlak rata-rata sebesar 2,89 m, dan nilai korelasi koefisien sebesar 0,802. Menurut Anderson dan Woessner (1992) nilai kalibrasi dianggap mendekati lapangan apabila nilai kalibrasi kurang dari $1 \mathrm{~m}$ dan nilai korelasi koefisien mendekati angka 1, sehingga nilai 
kalibrasi ini dinilai kurang memuaskan. Perlu dilakukan kalibrasi ulang terhadap parameter masukan model.

\section{Kalibrasi Model}

Nilai kalibrasi (Gambar 8) dilakukan dengan metode "curve fitting", yaitu dengan membandingkan nilai MAT terukur dan MAT terhitung dengan analisis perhitungan statistik, seperti mencari nilai akar kesalahan rata-rata (RMSE), kesalahan rata-rata (ME), dan kesalahan mutlak rata-rata (MAE) pada persamaan 2, 3, dan 4 (Spitz dan Moreno, 1996).

$$
\begin{aligned}
R M S E & =\sqrt{\frac{1}{n} \sum_{i=1}^{n}(h m-h s)^{2}} \\
M E & =\frac{1}{n} \sum_{i=1}^{n}(h m-h s) \\
M A E & =\frac{1}{n} \sum_{i=1}^{n}(|h m-h s|)
\end{aligned}
$$

Keterangan:

$$
\begin{array}{ll}
h m & =\text { MAT terhitung }(\mathrm{m}) \\
h s & =\text { MAT terukur }(\mathrm{m}) \\
n & =\text { Luasan watershed }
\end{array}
$$

Menurut Anderson dan Woessner (1992), analisis kalibrasi pada model dilakukan dengan proses coba-coba (trial and error) secara manual terhadap parameter masukan model hingga didapatkan nilai kalibrasi yang dianggap paling baik dengan nilai nilai akar kesalahan rata-rata (RMSE) sebesar $0,75 \mathrm{~m}$, kesalahan rata-rata (ME) sebesar 0,1 m, dan kesalahan mutlak ratarata (MAE) sebesar $0,63 \mathrm{~m}$, dengan nilai koefisien korelasi sebesar 0,944 (Gambar 9).

\section{Skenario Model}

Skenario model yang dilakukan terhadap model yaitu untuk memprediksi pengaruh pengambilan dan pemanfaatan airtanah oleh penduduk terhadap kondisi muka airtanah di daerah model, yaitu dengan mengamati selisih muka airtanah dan menghitung persentase selisih muka airtanah dalam kurun waktu dua puluh tahun kedepan dengan interval skenario per lima tahun.

Adapun data tambahan yang diperlukan berupa: data jumlah penduduk kabupaten, data dan kebutuhan rata-rata air bersih masyarakat Indonesia. pertumbuhan penduduk rata-rata, data jumlah sektor industri,

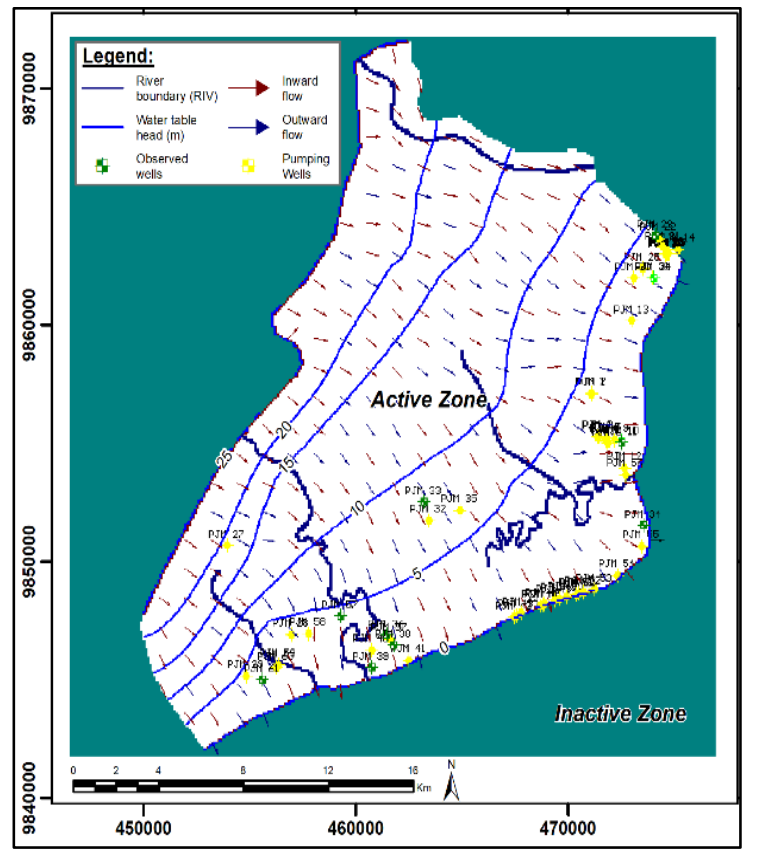

Gambar 8. Hasil pemodelan terkalibrasi.

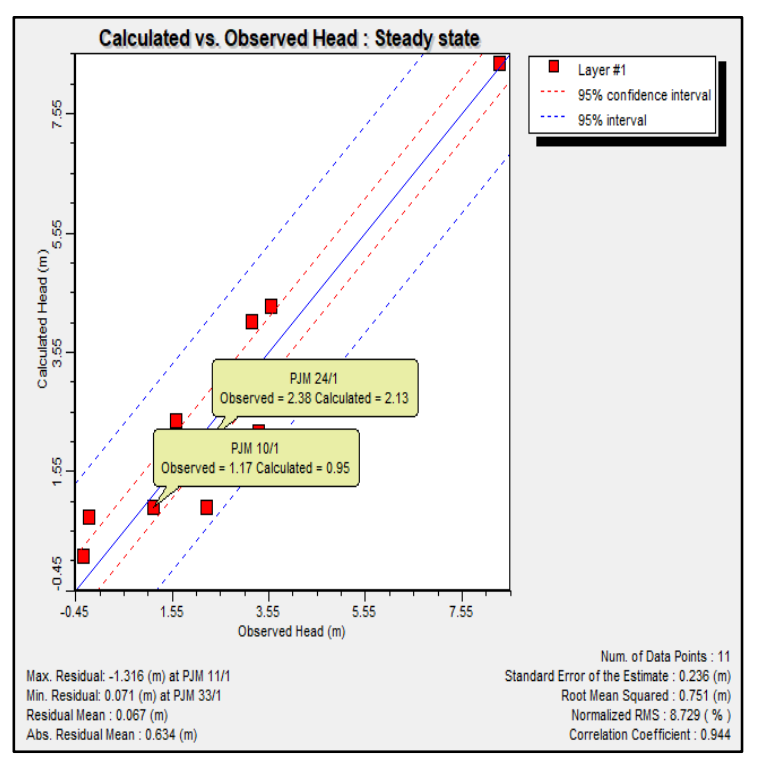

Gambar 9. Nilai kalibrasi model terkalibrasi

Data tersebut digunakan untuk perhitungan prediksi debit airtanah yang diambil akan dimasukkan kedalam model. Terdapat tiga skenario yang dilakukan antara lain yaitu:

a. Skenario I

Didapatkan selisih penurunan muka airtanah sebesar $0,38 \mathrm{~m}$ ditahun 2021; $0,41 \mathrm{~m}$ ditahun 2026; 0,43 m ditahun 2030; dan 0,45 m ditahun 2036. Persentase penurunan maksimum didaerah model umumnya kurang dari 40\% (Gambar 10). 


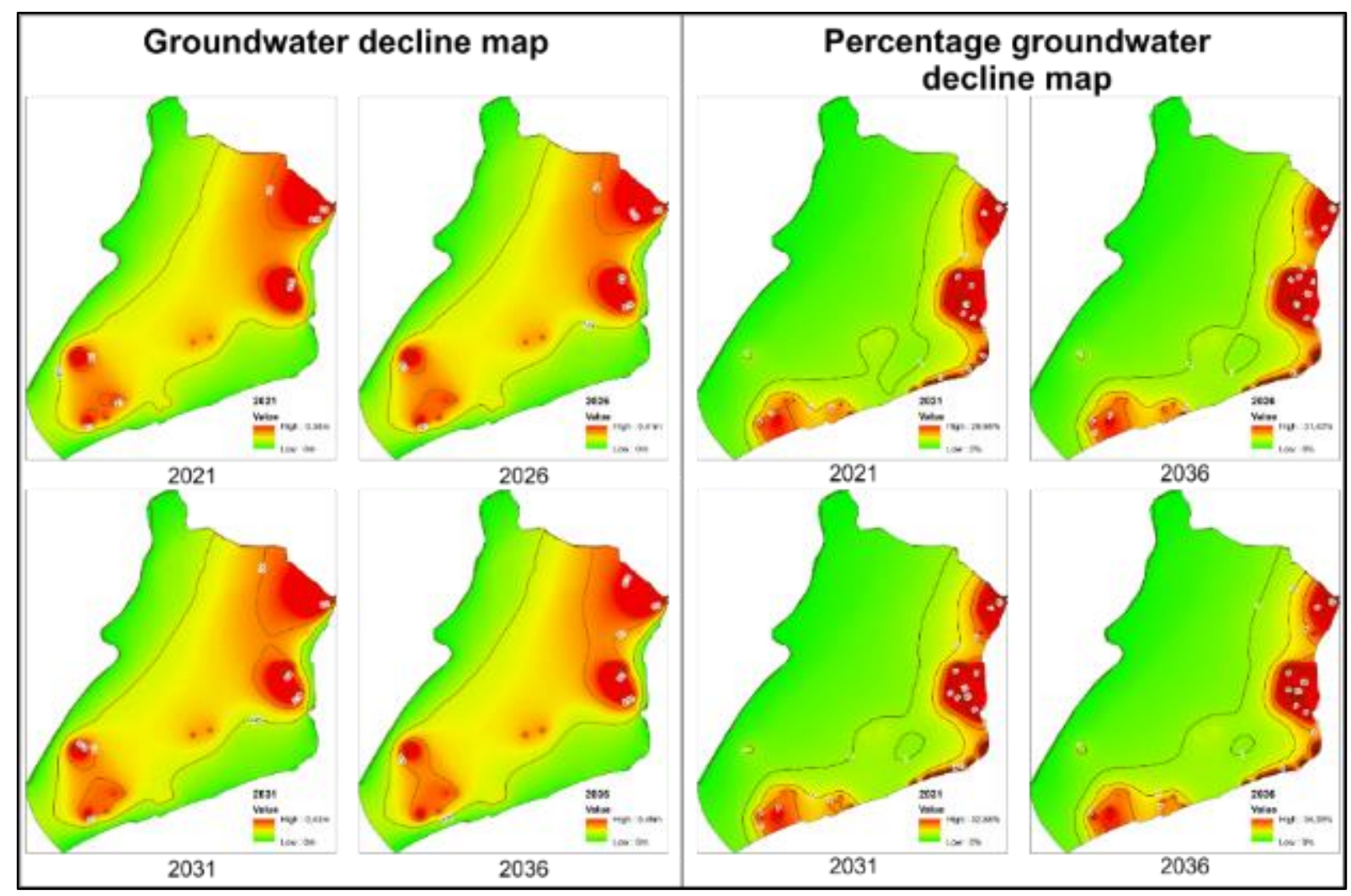

Gambar 10. Penurunan muka airtanah pada skenario I.

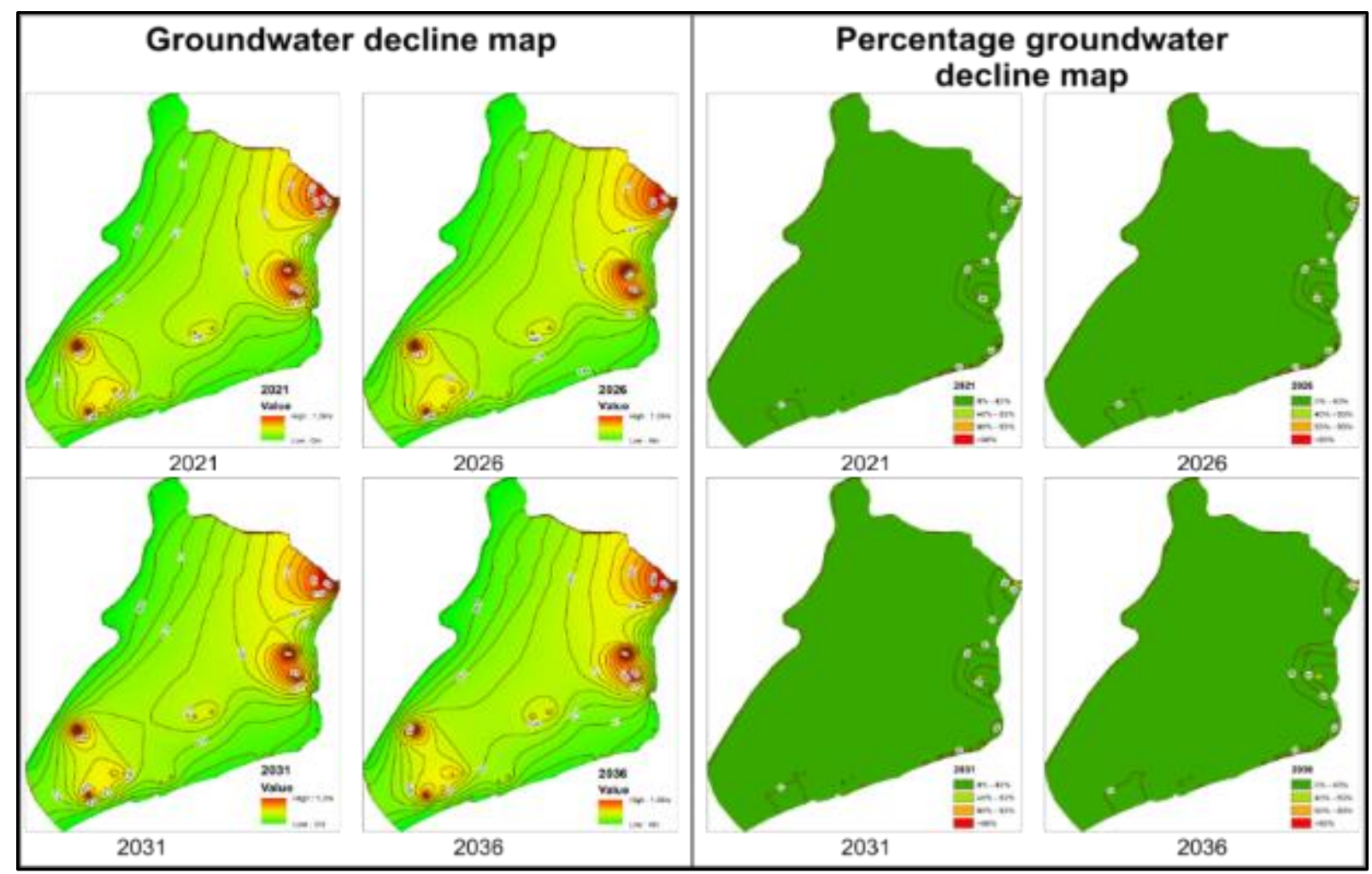

Gambar 11. Penurunan muka airtanah pada skenario II. 
b. Skenario II

Didapatkan selisih penurunan muka airtanah sebesar 1,26 m ditahun 2021; 1,28 m ditahun 2026; 1,3 m ditahun 2031; dan 1,36 m ditahun 2036. Persentase penurunan maksimum yang terjadi hingga lebih dari 80\% (kritis), namun ketika dilakukan pembagian zona persentase dengan nilai tertentu, daerah yang mengalami persentase penurunan muka airtanah lebih dari $80 \%$ hanya bersifat lokal dan tidak mempengaruhi muka airtanah secara regional/ (Gambar 11).

c. Skenario III

Didapatkan selisih penurunan muka airtanah sebesar 2,36 m ditahun 2021;2,4 m pada tahun 2026; 2,44 m pada tahun 2031; dan 2,58 $\mathrm{m}$ pada tahun 2036. Persentase penurunan maksimum yang terjadi lebih dari $80 \%$. Penurunan muka airtanah untuk penurunan antara 40\%-80\% terlihat secara regional. Penurunan lebih dari $80 \%$ masih terlihat lokal (Gambar 12).

\section{PEMBAHASAN}

\section{Zona Konservasi Airtanah}

Skenario konservasi airtanah dilakukan dengan meng-overlay data daya hantar listrik (DHL), peta zona imbuhan dan lepasan, dan persentase penurunan airtanah berdasarkan pemodelan. persentase penurunan airtanah berupa nilai persentase dari hasil simulasi model pada tahun 2036 pada skenario III. Hal ini dimaksudkan untuk mengetahui prediksi konservasi airtanah pada skenario yang terburuk.

Dalam pembuatan skenario konservasi airtanah ini digunakan klasifikasi zona konservasi airtanah menurut Danaryanto, dkk. (2007). Didapatkan empat zona prediksi konservasi airtanah (Gambar 13), antara lain:

a. Zona Perlindungan Airtanah

Cakupan zona ini sebesar 26,39\% (107,69 $\mathrm{km}^{2}$ ) dengan penurunan muka airtanah $<40 \%$ $(0-1 \quad m)$ dan nilai DHL 205-622 $\mu \mathrm{S} / \mathrm{cm}$ meliputi daerah Api-Api, Bangunmulyo, Buluminung, Girimukti, Giripurwa, LaweLawe, Nenang, Nipah-Nipah, Petung, Sesutu, Sotek, dan Waru.

b. Zona Aman

Cakupan zona ini sebesar 56,21\% (229,35 $\mathrm{km}^{2}$ ) dengan penurunan muka airtanah $<40 \%$ $(1,1-2,13 \mathrm{~m})$ dan nilai DHL $182-1.000 \mu \mathrm{S} / \mathrm{cm}$ meliputi daerah Api-Api, Bangunmulyo, Buluminung, Gersik, Girimukti, Giripurwa, Gunung Seteleng, Lawe-Lawe, Nenang, Nipah-Nipah, Penajam, petung, Sepan, Sesutu, Sidorejo, Sungai Parit, Tanjung Tengah, dan Waru.

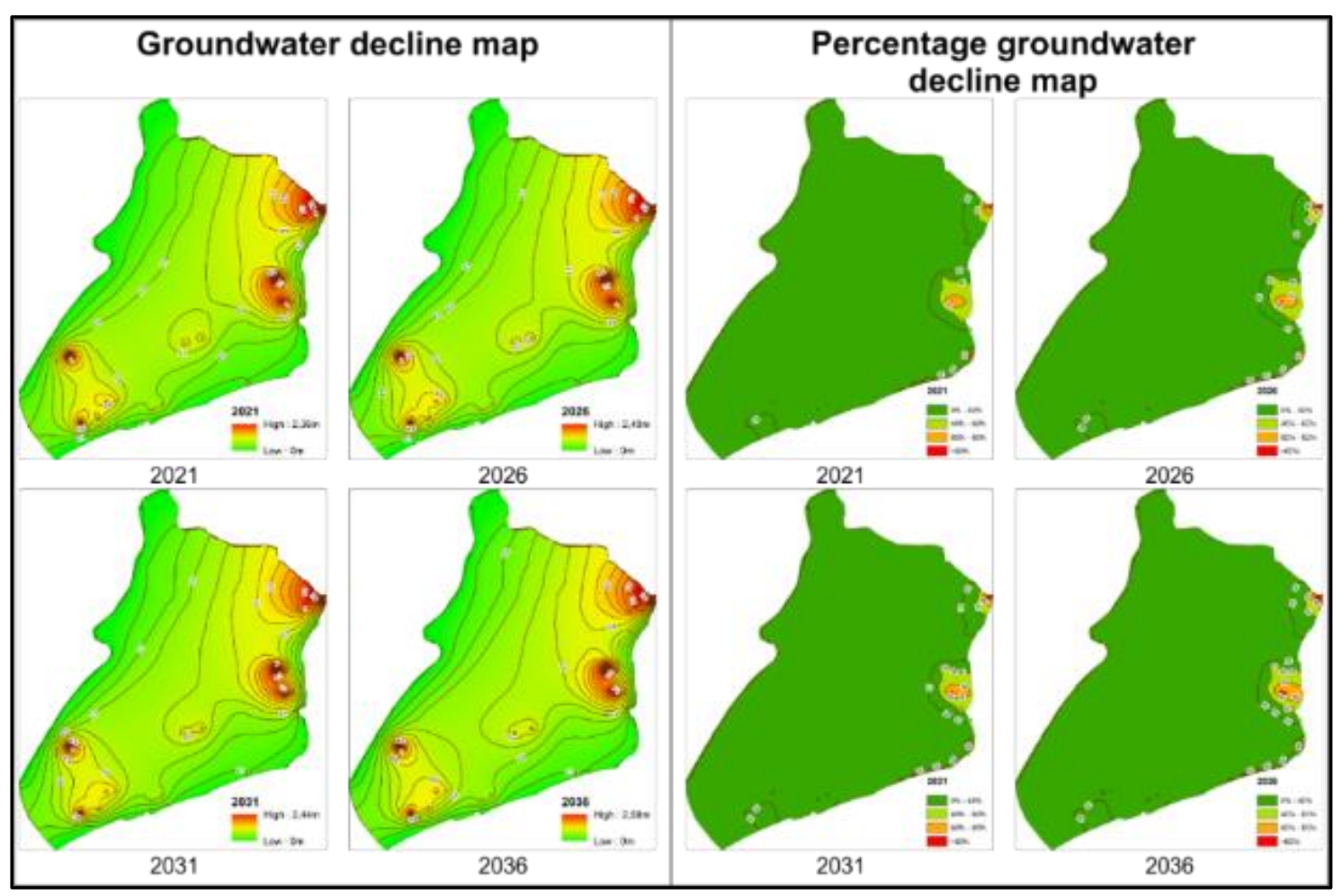

Gambar 12. Penurunan muka airtanah pada skenario III. 


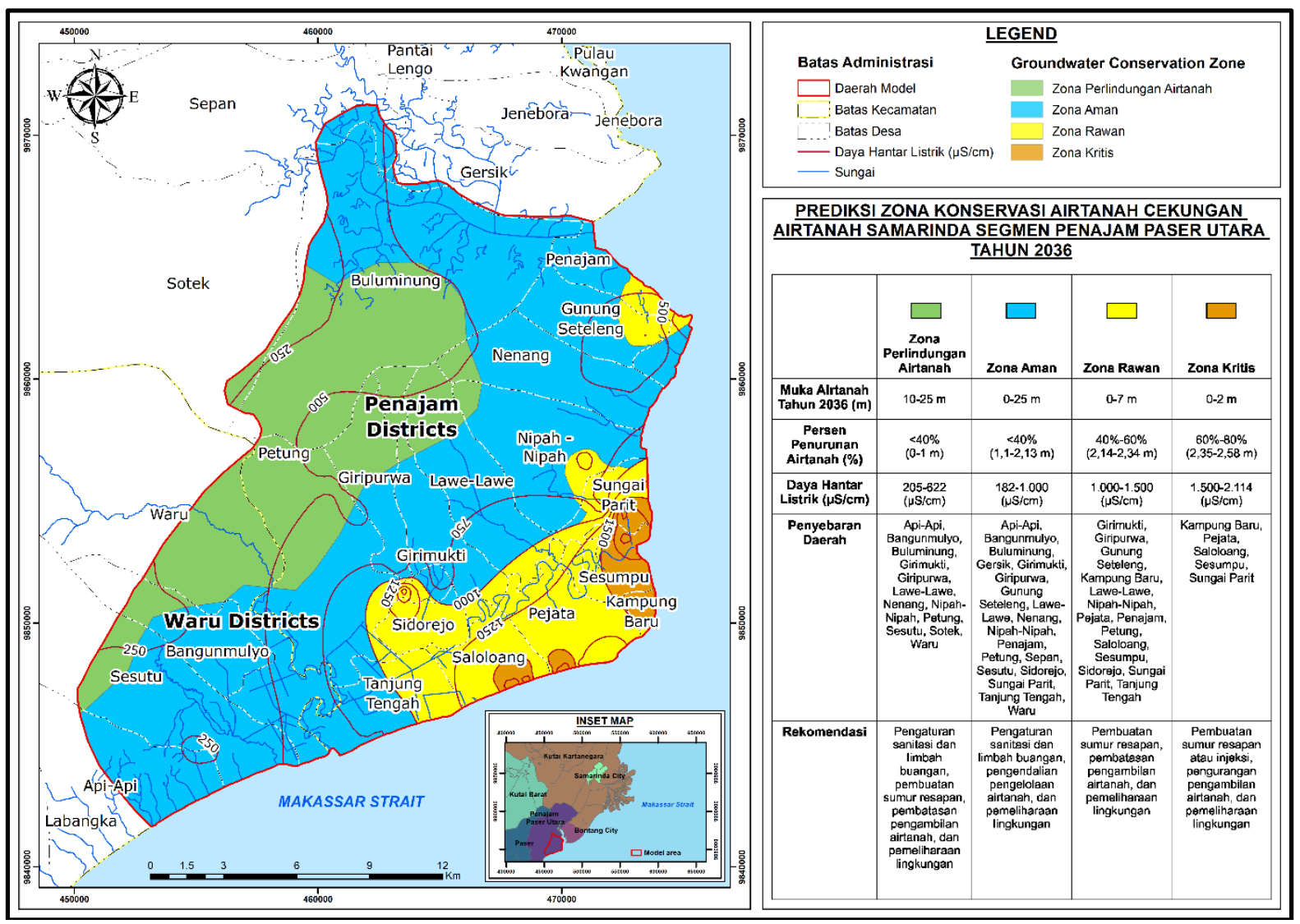

Gambar 13. Prediksi zona konservasi airtanah Cekungan Airtanah Samarinda-Bontang pada tahun 2036.

c. Zona Rawan

Cakupan zona ini sebesar $14,79 \%\left(60,35 \mathrm{~km}^{2}\right)$ dari total area cekungan airtanah SamarindaBontang segmen Penajam dengan penurunan muka airtanah 40\%-60\% (2,14-2,34 m) dan nilai DHL 1.000-1.500 $\mu \mathrm{S} / \mathrm{cm}$ meliputi daerah Girimukti, Giripurwa, Gunung Seteleng, Kampung Baru, Lawe-Lawe, Nipah-Nipah, Pejata, Penajam, Petung, Saloloang, Sesumpu, Sidorejo, Sungai Parit, dan Tanjung Tengah.

d. Zona Kritis

Cakupan zona ini sebesar 2,61\% (10,64 km²) dari total area cekungan airtanah SamarindaBontang segmen Penajam dengan penurunan muka airtanah 60\%-80\% (2,35-2,58 m) dan nilai DHL 1.500-2.114 $\mu$ S/cm meliputi daerah Kampung Baru, Pejata, Saloloang, Sesumpu, Sungai Parit.

\section{KESIMPULAN}

Aliran airtanah di daerah penelitian mengalir relatif dari arah barat menuju ke arah timur. Skenario pemompaan yang dihasilkan menunjukkan bahwa skenario III menunjukkan hasil prediksi penurunan MAT yang terburuk dibandingkan skenario I dan II. Dari hasil skenario pemompaan tersebut dihasilkan empat zonasi prediksi zona konservasi airtanah. Rekomendasi terkait konservasi airtanah berdasarkan model, masing-masing zona adalah:

a. Zona Perlindungan Airtanah

Pengaturan sanitasi dan limbah buangan, pembuatan sumur resapan, pembatasan pengambilan airtanah, dan pemeliharaan lingkungan.

b. Zona Aman

Pengaturan sanitasi dan limbah buangan, pengendalian pengelolaan airtanah, dan pemeliharaan lingkungan.

c. Zona Rawan

Pembuatan sumur resapan, pembatasan pengambilan airtanah, dan pemeliharaan lingkungan.

d. Zona Kritis

pembuatan sumur resapan atau injeksi, pengurangan pengambilan airtanah, dan pemeliharaan lingkungan. 


\section{UCAPAN TERIMA KASIH}

Dengan selesainya penelitian ini kami ucapkan terima kasih kepada Irwan Susilo dan Dwi Ahmad Romdoni selaku pihak dari PT. Geospasia Wahana Jaya yang mengizinkan untuk pengambilan data lapangan, serta Ario Geger dan Imaduddin Yazid yang membantu dalam pengambilan data lapangan dan pengolahan data.

\section{DAFTAR PUSTAKA}

Badan Pusat Statistik Kabupaten Penajam Paser Utara, 2017, Kabupaten Penajam Paser Utara Dalam Angka 2017. Badan Pusat Statistik Kabupaten Penajam Paser Utara: Penajam.

Chow, V.T., Maidment, D.R., dan Mays, L.W., 1998, Applied Hydrology. McGraw-Hill Book Company: New York.

Cornelia, S.B., 2004, Pemodelan Dan Analisis Kimia Airtanah dengan Menggunakan Software Modflow di Daerah Bekas Tpa Pasir Impun Bandung, Jawa Barat. Institut Teknologi Bandung: Bandung.

Danaryanto, T. H., Setiadi H., dan Siagian, Y., 2007, Kumpulan Panduan Teknis Pengelolaan Air Tanah. Departemen Energi dan Sumber Daya Mineral, Badan Geologi, Pusat Lingkungan Geologi: Bandung.

Hendrayana, H., 2011, Penetapan Program Pengelolaan Airtanah Di Cekungan Airtanah Yogyakarta-Sleman.UGM Press: Yogyakarta.

Hidayat, S., dan Umar, I., 1994, Peta Geologi Lembar Balikpapan Kalimantan, Bandung: Pusat Penelitian dan Pengembangan Geologi 1814, skala 1:250,000.

Kementerian ESDM, 2017, Peraturan Menteri Energi dan Sumber Daya Mineral Nomor 2 Tahun 2017 Tentang Cekungan Airtanah di Indonesia.

Margono, B., 1995, Peta Hidrogeologi Lembar Balikpapan, skala 1:250.000. Direktorat Geologi Tata Lingkungan: Bandung.

McDonald, M. G., dan Harbaugh, A.W., 1988, A Modular Three-Dimensional FiniteDifference Ground-Water Flow Model, OpenFile Report No. 83-875.

Spitz, K dan Moreno, J., 1996, A Practical Guide to Groundwater and Solute Transport Modeling, John Wiley \& Sons Inc.: New York. 